\section{Kastamonu Eğitim Dergisi Kastamonu Education Journal}

Ocak 2019 Cilt:27 Sayı:2

kefdergi.kastamonu.edu.tr
Başvuru Tarihi/Received: 14.01.2018

Kabul Tarihi/Accepted: 15.05.2018

DOI: $10.24106 /$ kefdergi.2560

\title{
Genç Yetişkinlerin Aldatmaya Yönelik Niyetleri Üzerinde Aldatmaya Yönelik Tutum Ve Sosyal Medya Kullanımının Etkisi
}

\section{The Effect Of Using Social Media and Attitudes Towards Infidelity on the Intentions Towards İfidelity Among Young Adults}

\section{Özet}

\author{
Asiye DURSUN ${ }^{1}$, Murat Sinan ÖZKAN ${ }^{2}$
}

Genç yetişkinlik, mesleki hayata başlama ve eş seçme gibi gelişim görevlerini barındıran dönemlerden biridir. Gelişen teknoloji ve internetin yaşamın birçok alanında olması ile genç yetişkinler, yoğun şekilde sosyal medya kullanmakta, ilişki başlatma ve sürdürme konusunda sosyal medyayı tercih etmektedir. Aynı zamanda bireylerin romantik ilişkileri bazen aldatma ile zarar görebilmektedir. Bu araştırma, sosyal medya kullanımın bu denli yoğun olduğu genç yetişkinlik döneminde, aldatma olgusunun sosyal medya kullanımı ile ilişkisini irdelemeyi amaçlayan betimsel bir çalışmadır.Araştırma grubunu 293 (\%72.7)kadın, 110 (\%27.3)erkek olmak üzere toplam 403 genç yetişkin oluşturmaktadır.Araştırmada, sosyal medya kullanım ölçeği, aldatmaya yönelik tutum ve aldatmaya yönelik niyet ölçeği kullanılmıştr. Araştırma bulgularına göre genç yetişkinlerin cinsiyet değişkenine ilişkin cinsel deneyim ve ilişki dur,umuna göre çapraz tablo sonuçları incelenmiştir. Ayrıca genç yetişkinlerin aldatmaya yönelik niyetlerini ne derece açıkladıkları regresyon analizi ile incelenmiş ve açıklayıcı değişkenlerin yani; cinsiyet, sosyal medya kullanımı, olumlu-olumsuz aldatmaya yönelik tutum (aldatmaya yönelik tutum ölçeği alt boyutları) değişkenleri aldatmaya yönelik niyet değişkenini anlamlı şekilde yordadığı görülmüştür.

Anahtar Kelimeler: Genç yetişkin, aldatma, sosyal medya kullanımı

\section{Abstract}

Young adulthood is one of the periods of developmental duties such as starting a professional life and choosing a spouse. With the help of developing technology and the intensive use of the internet, young adults use social media in intense ways and prefer social media to initiate and maintain relationships. At the same time, romantic relationships of individuals can sometimes be damaged by deception. This research is a descriptive study aimed at investigating the relationship between the use of social media and the use of social media in young adulthood. The study group consisted of 403 young adults $(293$ (72.7\%) female and $110(27.3 \%)$ male). Social media use scale, attitude towards deceit and intent to deceive scale were used in the research. According to research findings, the results of cross-tabulation according to sexual experience and relationship status of gender variable of young adults were examined. In addition, the extent to which young adults exploit their intent to deceive was examined by means of regression analysis. gender, use of social media, attitudes towards positive-negative deception (attitude scale subdimensions for deception) significantly predicted the intention to deceive variables.

Keywords: Young adults, infidelity, social media use

1. Anadolu Üniversitesi, Rehberlik ve Psikolojik Danışmanlık Bölümü Doktora Öğrencisi, Eskişehir, Türkiye; https://orcid.org/0000-0002-4033-0034 2. Uludağ Üniversitesi, Rehberlik ve Psikolojik Danışmanlık Bölümü Doktora Öğrencisi, Bursa, Türkiye; https://orcid.org/0000-0002-6118-9658 etkisi. Kastamonu Education Journal, 27(2), 475-495. doi:10.24106/kefdergi.2560 


\section{Extended Summary}

Purpose: People go through some developmental periods throughout their lives. From the theorists dealing with these developmental periods, Erikson states that the areas of cognitive, social, psychological and physical development that existed during the developmental stages affect the communication process. One of the developmental stages is young adulthood. This period is one of the periods that include developmental duties such as starting a professional life and choosing a spouse. With the help of developing technology and the intensive use of the internet, young adults use social media in intense ways and prefer social media to initiate and maintain relationships. Deception is dealt with as a combination of romantic emotional and sexual intimacy, in which one within the loyalty relationship violates the norms of another, untrusted, or accepted apart from this primary relationship. For this reason, it is important to investigate the relationship between intention to deceive behavior and social media use in romantic relationships that is important in young adulthood.

Method: Thisstudy is a descriptive study aimed at determining there relationship between the use of findings and social media such as the view point of young adults' relationship and sexuality, and there relationship between deception and deceit intention. For research descriptive statistics, relational model (regression and correlation) is used for the percent-frequency and the predictors of intent to deceive. There search group was obtained by means of non-probative sampling. There search group of this study consists of 293 (72.7\%) female and 110 (27.3\%) male, 403 people. In the analysis of the data obtained in the study, SPSS 21 package program was used. The variance and kurtosis values of the variables with and without normal distribution were evaluated with variance homogeneity and $\mathrm{N}>30$. Kurtosis values ranged from .04to .82; Swekness values were determined between -04 and .97. Observed values, kurtosis values between -2 and +2 ; Swekness values were within -1.96 and +1.96 normality limits, and $p$ value was found to be at 0.05 significance level. Descriptive statistics were used to look the proportion of variables related togender, relationship status, and sexual experience perspective of young adults. There relationship between intention to deceive, use of social media and attitudes towards deceit has been examined through the analysis of collage. Multiple regression analysis was used to look at whether social media use and attitudes toward deceit predicted the intent to deceive.

Results: When the crosstan is examined $100 \%$ of young adults who say yes togender-male and currentand continuing relationships have sexual experience in life; where as $43 \%$ of the women who said yes to currentand continuing relationships had sexual experience; the currentand continuing relationship is that the women who say no have no $100 \%$ of the sexual experience.

The extent to which young adult sex ploit their intent to infidelity was examined by means of regression analysis and thee xplanatory variables, gender, social media use, attitudes towards positive deception, and attitudes toward negative infidelity (attitude scales ubdimensions for infidelity) significantly predicted the intention to deceive variables. When the multiple regression table is examined, gender variables (analyzed by regulating dummy variables for a categorical variable, the effect of being male or female), All explanatory variables have individual significance in explaining dependent variables.

Discussion: When the cross table on the first finding is examined, when it is examined, while having sexual experience in the experience of male adults continuing to the relationship, it is seen that female adults who continue to have relationships do not have sexual experience. The extent to which young adults exploit their intent to infidelitywas examined by means of regression analysis. gender, use of social media, attitudes towards positive-negative infidelity (attitude scale subdimensions for infidelity) significantly predicted the intention to infidelity variables. The extent to which young adults exploit their intent to infidelity was examined by means of regression analysis. gender, use of social media, attitudes towards positive-negative infidelity (attitude scale subdimensions for infidelity) significantly predicted the intention to infidelity variables.

Result: In this study, different results were obtained in young adults according to various variables and intention to infidelity scale. According to these results, it can be suggested that it is useful to organize psychosocial intervention groups to reduce the deceptive behaviors of the individuals, to give conferences, seminars and educational contents about the damages and possible consequences of the deception behavior and social media usage by the experts. 


\section{Giriş}

İnsanlar yaşamları boyunca bazı gelişim dönemlerinden geçmektedir. Bu gelişim dönemlerini ele alan kuramcılardan Erikson, gelişim dönemlerinde var olan bilişsel, sosyal, psikolojik ve fiziksel gelişim alanlarının iletişim sürecini etkilediğini ifade etmektedir (Ross, 2006). Ele alınan gelişim süreçlerinden biri de genç yetişkinliktir. Genç yetişkinlik döneminin gelişim görevi ise yakınlığa karşı yalıtılmışlıktır. İletişim daha çok romantik ve yakın ilişkiler kurma konusunda yoğunlaşmaktadır. Bu yüzden genç yetişkinler için evlilik ve mesleki kariyer öncelikli hale gelmektedir. Genç yetişkinlik dönemi sağlıklı şekilde atlatıldığında kişi güvenli bir şekilde sevgi gösterme ve kabul gücüne sahip olmaktadır. Aksi takdirde, ilişki kuramayan kişi psikolojik bir yalnızlık yaşayabilmektedir (Lehr, 1994). Bu nedenle genç yetişkinlik döneminde iletişimin ve romantik ilişkilerin önemi oldukça artmaktadır.

Iletişim, geçmişten günümüze insan hayatında gereksinim duyulan ihtiyaçlardan biridir. Küreselleşme ve gelişen teknoloji ile birlikte kişilerarası iletişimde de değişimler yaşanmaktadır. Yüz yüze gerçekleştirilen iletişim, yaşanan değişimlerle birlikte yerini sanal ortamlarda gerçekleştirilen iletişime bırakmaktadır. iletişim teknolojilerinde bilgisayar ve internet temel bir öneme sahip olmasına rağmen iletişimi sağlamak için yeterli olmayabilmektedir.Bu durum sosyal medya ve sosyal ağlar denilen unsurların gündeme gelmesine ortam hazırlamaktadır. Sosyal medyada iletişim fotoğraflar, videolar, kelimeler ve ses dosyaları ile sağlanmakta, insanlar tecrübelerini, hayat hikâyelerini ve durumlarını paylaşmaktadırlar (Bostancı, 2010). Genç yetişkinlerin \% 75'i de iletişim için interneti kullanmaktadır.Aynı zamanda bir ya da birden fazla sosyal paylaşım sitesinde, aktif sosyal medya kullanıcısı olarak zamanlarını geçirmektedirler (Küçükali, 2016). Bu bilgiler doğrultusunda iletişim ve ilişki sürecinde, internet ve sosyal medyanın genç yetişkinler için oldukça önemli olduğu söylenebilir.

Genç yetişkinlerin sosyal medya ve sosyal ağlarla ilişkisine bakıldığında, hemen her gün internete girdikleri ve internette geçirilen süreyi genellikle sosyal ağlarda harcadıkları bilinmektedir (Vural ve Bat, 2010). Genç yetişkinlerin \%95'inin sosyal ağlara girmek için interneti kullandığı, \%75,7'sinin favori web sitesinin Facebook olduğu, \%99,0'unun her gün internet kullandığı, \%16,4'ününsosyal ağları online sohbet etmek için kullanması da durumu destekler niteliktedir (Dikme, 2013). Genç yetişkinlerin sosyal medyayı tercih etmesinin çeşitli nedenleri olabileceği düşünülebilir.

Sosyal medyanın, insanların internet aracılığıyla yer ve zaman sınırlaması olmaksızın düşüncelerini ve görüşlerini belirtmelerine olanak vermesi, internetin sağladığı multimedya özelliklerini sınırsız bir şekilde kullanım imkânı tanıması, aynı zamanda diğer insanlarla görüş alışverişine ve paylaşıma dayalı etkileşimsel bir ortam sunması (Bulunmaz, 2011) genç yetişkinler için tercih edilme olasılığını artırdığı düşünülebilir. Bunun dışında sosyal medyanın; kişilerarası ikna, insanların düşüncelerini ve davranışlarını değiştirmek üzere odaklandığı bilinmektedir. Yani sosyal medya ile doğrudan rica etmek, aldatmak,yakınlık göstermek, iltifat etmek, övmek, diğerlerine uymak, kendini göstermek, iltimas geçmek, ayrıcalık tanımak, tanınma, rekabet ve işbirliği/dayanışma, sosyal kabul gibi sosyal etkileme stratejileri kullanılmaktadır (Yeygel ve Çakır, 2011).Genç yetişkinlerin \%48'inin sosyal medyada kendilerini gerçek hayattakinden çok daha rahat hissetmeleri de (Ergenç, 2011) bu stratejileri rahat bir şekilde kullanmayı tercih ettiklerini kanıtlar niteliktedir. Bu nedenle genç yetişkinlerin gerçek hayatta göstermekten çekindikleri risk alamadıkları davranışları sosyal medyada sergileyebilecekleri düşünülebilir. Bu dönemde yakın ilişki kurmaya çalışan genç yetişkinler yakın ilişkilerin önemli bir öğesi olan romantik ilişkiye de önem vermektedirler. Romantik ilişkilerde ise bağlanma, duygusal, bilişsel ve fiziksel yakınlık, karşılıkılık olmak üzere beş faktör üzerinde durulmaktadır (Moss ve Schwebell, 1993). Romantik ilişkilerde bu faktörlerde yaşanacak sıkıntılarda aldatma ile karşılaşılabilmektedir.

illişkide eşi aldatma; bağılık ilişkisi içindeki birinin, birincil olan bu ilişkisi dışında başka biriyle, güveni zedeleyici veya kabul gören normların ihlal edildiği, romantik duygusal ve cinsel yakınıı içeren birlikteliği olarak ele alınmaktadır (Blow ve Hartnett, 2005). Genç yetişkinlikte var olan flört ilişkisinde aldatma durumuna bakıldığında; erkeklerin \%70.9'unun, kadınların ise \%54.4'ünün (Hansen, 1987); erkeklerin \%75'inin kadınların da \%68'inin (Wiederman ve Hurd, 1999) ilişki dışı bir aldatma davranışı gösterdikleri bilinmektedir. İlişkilerde eşi aldatma ile ilgili araştırmalara bakıldığında; aldatma için tutumların değil niyetlerin incelenmesi gerektiğini belirtmektedir. Çünkü;niyetlerin davranışa dönüşme olasılığının tutumlardan daha fazla olduğu bilinmektedir (Jones, Olderbak ve Figueredo, 2011). Bununla birlikte aldatma davranışının anlaşılabilmesi için tutum-niyet (Azjen ve Fishbein, 2005)ilişkisinin önemli olduğu düşünülmektedir. Bu araştırmada genç yetişkin döneminde önemli olan romantik ilişkilerde aldatma davranışında niyetin aldatmaya yönelik ve sosyal medya kullanımı ile ilişkisi irdelenmektedir. Yakın ilişki kurmanın, genç yetişkinlik döneminin gelişim görevi olduğu ele alındığında; genç yetişkinlerin yaşayabilecekleri ilişkilerin irdelenmesinin önemli olduğu düşünülmektedir. Özellikle ilişki sürecine zarar veren aldatma olgusuna yönelik niyetinin ele alınması; tutum ve yoğun düzeyde kullanıldığı bilinen sosyal medya ile ilişkisinin ne olduğuna dair mevcut bilgilerin ortaya konulmasının önemli olduğu düşünülmektedir. Ayrıca araştırma alanyazında genç yetişkinlerin aldatma yaşantıları ile ilgili sunacağı bilgiler ile aldatma olgusunu 
daha anlaşıır kılacağı düşünülmektedir. İlgili değişkenlerle yapılan başka bir araştırma bulunmadığı için alanyazına katkı sağlayacağı düşünülmektedir. Yine sosyal medya kullanımının yoğun olduğu genç yetişkinlik döneminde romantik ilişkilerin ne şekilde etkilendiğini bilmek ve bir takım önleyici çalışmalar yapmak için faydalı olacağı düşünülmektedir. Bu amaçla araştırmada şu hipotezlere cevap aranmaktadır;

- Genç yetişkinlerin cinsiyet, ilişki durumları ve cinsel deneyime bakış açıları arasında ilişki vardır.

- Genç yetişkinlerin cinsiyet, sosyal medya kullanımı ve aldatmaya yönelik olumlu - olumsuz tutumları, aldatmaya yönelik niyetlerini yordamaktadır.

\section{Yöntem}

\section{Araştırma Modeli}

Bu çalışma, genç yetişkinlerin ilişki durumu ve cinsel birlikteliğe bakış açısı gibi bulgular ve sosyal medya kullanımı, aldatma tutumu ile aldatma niyeti arasındaki ilişkiyi belirlemeyi amaçlayan betimsel bir çalışmadır. Araştırma betimsel istatistikler için yüzde-frekans ve aldatma niyetinin yordayıcıları için ilişkisel model (regresyon ve korelasyon) kullanılmıştır. Regresyon, bir ya da daha fazla bağımsız değişkenin bağımlı değişken üzerindeki etkisini belirlemek ve nedensel yorumlamalar yapmak için kullanılan bir analizdir (Gürbüz ve Şahin, 2017).

\section{Araştırma Grubu}

Gönüllü kathlımcılara Google form uygulaması kullanılarak 2017 Ekim ve Aralık aylarında internet aracılığıyla sosyal medya "Facebook" kanalıyla ulaşılmıştır. Araştırma grubu olasılıklı olmayan amaçlı örnekleme yolu ile elde edilmiştir. Bu çalışmanın araştırma grubunu 293 (\%72.7) kadın, 110 (\%27.3)erkek olmak üzere toplam 403 kişi oluşturmaktadır. 363 (\%90.1), kişi lisans mezunu 36 (\%8.9) kişi yüksek lisans mezunu, 4 (\%1) kişi ise doktora mezunudur. Şuan devam eden ilişkisi olan 241 (\%59.8) kişi, ilişkisi bulunmayan 162 (\%40.2) kişi bulunmaktadır. Sosyal medya kullanım saatlerine bakıldığında 38 (\%9.4) kişi bir saatten az, 157 (\%41.4) kişi 1-2 saat, 163 (\%40.4) kişi 2-5 saat, 35 (\%8.7) 5 saatten fazla sosyal medyada vakit geçirmektedir.

\section{Veri Toplama Araçları}

Aldatmaya Yönelik Tutum Ölçeği:Flört ilişkisinde aldatmaya yönelik tutumu ölçmek için Whatley (2008) tarafindan geliştirilmiş bir ölçektir. 7'li likert tipi bir ölçek olan Aldatmaya Yönelik Tutum Ölçeği 6'sı tersine puanlanan12 maddeden oluşmakta ve tek faktör altında toplanmaktadır. Uyarlama çalışması Toplu-Demirtaş, Dolunay-Çuğ ve Tezer (2014) tarafindan yapılan ölçeğin Türkçe formu ise olumlu ve olumsuz olmak üzere iki faktör ve 6'sı tersine puanlanan12 maddeden oluşmaktadır. Uyarlanan ölçeğin iç tutarlık katsayısı. 80 olarak bulunmuştur. Cronbach alfa iç tutarlılık güvenirlik kat sayısı, .80 olarak bulunmuştur. Bu araştırmada ise Cronbach alfa iç tutarlılık güvenirlik kat sayısı, .78 olarak bulunmuştur. Ölçekten alınan en düşük puan 7 en yüksek puan 84 'tür ve ölçekten alınan yüksek puanlar aldatmayı kabul edici bir tutuma işaret etmektedir.

Aldatmaya Yönelik Niyet Ölçeği: Romantik ilişkide bireyin eşini aldatma olasılığını değerlendirmek, aldatmaya yönelik niyetini ve eğilimini ölçmek için Jones ve arkadaşları (2011) tarafindan geliştirilen ölçek Toplu- Demirtaş ve Tezer (2013) tarafindan Türkçe'ye uyarlanmıştır. 7'li likert tipinden olan ölçek 1'i tersine puanlanan 7 maddeden oluşmakta ve tek faktör altında toplanmaktadır. Cronbach alfa iç tutarlılık güvenirlik kat sayısı, .82 test tekrar test katsayısı .85 olarak bulunmuştur.Bu araştırmada ise Cronbach alfa iç tutarlılık güvenirlik kat sayısı, .65 olarak bulunmuştur. Ölçekten alınan en düşük puan 7 en yüksek puan 49'dur ve ölçekten alınan yüksek puanlar yüksek aldatma niyetine işaret etmektedir.

Sosyal Medya Kullanım Ölçeği:Sosyal medya kullanım durumunu belirlemek için Jenkins-Guarnieri, Wright ve Johnson (2013) tarafindan geliştirilen ölçek Akın, Özbay ve Baykut (2015) tarafindan Türkçe'ye uyarlanmıştr. Ölçek 6'lı derecelendirme içeren 10 maddeden oluşmakta ve tek faktör altında toplanmaktadır. Yüksek puanlar sosyal medya kullanım düzeyinin yükseldiğini göstermektedir. Sosyal Medya Kullanımı Ölçeği'nin Türkçeye uyarlanan formunun Cronbach alfa iç tutarlıık güvenirlik kat sayıları ölçeğin sosyal bütünleme ve duygusal bağlant alt ölçeği için .87; sosyal rutinlerle bütünleme alt ölçeği için .71, ölçeğin bütünü için .87 olarak bulunmuştur.Bu araştrrmada ise Cronbach alfa iç tutarlılık güvenirlik kat sayısı, .73 olarak bulunmuştur. Sosyal Medya Kullanımı Ölçeğinin düzeltilmiş madde-test korelasyonları.31 ile .76 arasında sıralanmaktadır.

Kişisel Bilgi Formu:Araştrmaya katılan genç yetişkinlere dair sosyodemografik bilgileri öğrenmek adına, cinsiyet, cinsel deneyim, devam eden romantik ilişki, mezuniyet ve günlük sosyal medya kullanım saatlerine dair soruların yer aldığı formdan oluşmaktadır. 
İşlem

Çalışmada kullanılan ölçekler katılımcılara sanal ortamda gönüllülük esasında dayalı olarak uygulanmıştır. Katılımcılara öncelikle araştırmanın amacına yönelik kısa bir bilgi verilmiş ve ardından uygulamaya geçilmiştir. Katılımcılardan kimlik bilgileri istenmemiştir. Ölçeklerin uygulanması 10- 15 dakika arasında değişmiştir.

\section{Verilerin Analizi}

Araştırmada elde edilen verilerin analizinde lisanslı SPSS 21 paket programı kullanılmıştır. Verilerin normal dağılım gösterip göstermediği değişkenlerin çarpıklık ve basıklık değerleri, varyans homojenliği ve $\mathrm{N}>30$ olması ile değerlendirilmiştir. Basıklık (Kurtosis) değerleri .04 ile .82 arasında; çarpıklık (Swekness) değerleri ise -.04 ve .97 arasında tespit edilmiştir. Gözlenen değerlerin, basıklık (Kurtosis) ve çarpıklık (Swekness) değerlerinin ise -1.96 ve +1.96 normallik sınırları içinde olduğu, $p$ değerinin ise 0.05 anlamlılık düzeyinde yer aldığı görülmüştür (Büyüköztürk, 2017). Genç yetişkinlerin cinsiyet, ilişki durumu ve cinsel deneyime bakış açısı ile ilgili değişkenlerin oranına bakmak için betimsel istatistik kullanılmıştr. Aldatmaya yönelik niyetin, sosyal medya kullanımı ve aldatmaya yönelik tutum ilişkisi ise kolerasyon analizi ile incelenmiştir. Sosyal medya kullanımı ve aldatmaya yönelik tutumun aldatma niyetini yordayıp yordamadığına bakmak için çoklu regresyon analizi kullanılmıştr. Verilerin normal dağılım sergilemesi, çoklu bağlant sorununun bulunmaması, bağımlı ve bağımsız değişkenlerin arasında var olan ilişkinin doğrusal olması, ve örneklemin yeterli büyüklüğü sahip olması bu gerekliliklerden bazılarıdır (Hair, Black, Babin ve Anderson, 2010). Araştırma kapsamında toplanan verilerin çok değişkenli normallik varsayımını karşılayıp karşılamadığı, Mahalanobis Uzaklığı ile belirlenmiş ve uzaklık değerlerinin $\left[\chi^{2}(5)=20.52, p=.001\right]$ üzerinde olan hiçbir veri olmadığı görülmüştür.Değişkenler arası korelasyon değerlerinin de -.35ile .79 arasında değiştiği belirlenmiştir. Elde edilen değerler incelendiğinde çoklu bağlant probleminin olmadığı ifade edilebilir. Ayrıca süreksiz değişken olan cinsiyet değişkenine kukla "dummy" değişkeni atanarak (Kız=1; Erkek=0) sürekli hale getirilerek regresyona uygun şartlar sağlanmıştır.

\section{Bulgular}

Araştırmada ilk olarak "Genç yetişkinlerin cinsiyet, ilişki durumları ve cinsel deneyime bakış açıları arasında ilişki vardır" hipotezine yönelik frekans ve yüzdelik değerlerine bakılarak çapraz tablo yapılmıştr. Sonuçlar Tablo 1' de verilmiştir.

Tablo 1. Genç Yetişkinlerin Cinsiyet Değişkenine İlişkin Cinsel Deneyim ve ilişsi Durumuna Göre Çapraz Tablo

\begin{tabular}{|c|c|c|c|c|c|c|}
\hline \multirow[b]{2}{*}{ Cinsiyet } & & & \multicolumn{3}{|c|}{ Cinsel Deneyim } & \multirow{2}{*}{ Toplam } \\
\hline & & & & Evet & Hayır & \\
\hline \multirow{2}{*}{ Erkek } & \multirow{2}{*}{ Şuanda devam eden ilişki durumu } & \multirow{2}{*}{ Evet } & $\mathrm{N}$ & 110 & 0 & 110 \\
\hline & & & $\%$ & 100 & & \\
\hline \multirow{4}{*}{ Kadın } & \multirow{4}{*}{ Şuanda devam eden ilişki durumu } & \multirow{2}{*}{ Evet } & $\mathrm{N}$ & 62 & 69 & 131 \\
\hline & & & $\%$ & 42,7 & 57,3 & 100 \\
\hline & & \multirow{2}{*}{ Hayır } & $\mathrm{N}$ & 0 & 162 & 162 \\
\hline & & & $\%$ & 0 & 100 & 100 \\
\hline \multirow{2}{*}{ Toplam } & & & $\mathrm{N}$ & 172 & 231 & 403 \\
\hline & & & $\%$ & 42,7 & 57,3 & 100 \\
\hline $\mathrm{X}^{2}$ & & & & & & $.60 * *$ \\
\hline
\end{tabular}

$* * \mathrm{p}<.01$

Tablo incelendiğinde ilişkilerine devam eden erkeklerin \%100'ü yaşantısında cinsel deneyime sahip iken; ilişkilerine devam eden kadınların \%43'ü cinsel deneyime sahip oldukları bulunmuştur. Ancak; ilişkisi olmayan kadınların \%100'ü ise cinsel deneyime sahip olmadıkları sonucu görülmektedir.

Araştırmanın son sorusu olan "Genç yetişkinlerin cinsiyet, sosyal medya kullanımı ve aldatmaya yönelik olumlu olumsuz tutumları, aldatmaya yönelik niyetlerini yordamaktadır." hipotezine yönelik korelasyon ve regresyon analizi yapılmıştır. Bulgularla ilgili değişkenler arası ilişkiler Tablo 2'de verilmiştir.

Tablo 2. Genç Yetişkinleri Aldatmaya Yönelik Niyet Toplam Puanları ile Aldatmaya Yönelik Tutum ve Sosyal Medya Kullanım Alt Boyutları Arasındaki ilişkiler ve Betimsel İstatistikler 


\begin{tabular}{lcccccc}
\hline & $\mathbf{1}$ & $\mathbf{2}$ & $\mathbf{3}$ & $\mathbf{4}$ & $\mathbf{5}$ & $\mathbf{6}$ \\
\hline AYNO & - & & & & & \\
Olumsuz AYT & $-.35^{* *}$ & - & & & & \\
Olumlu AYT & $.47^{* *}$ & $-.38^{* *}$ & - & & & \\
Sosyal Bütünleşme ve Duygusal Bağlant & $.25^{* *}$ & $.28^{* *}$ & $.33^{* *}$ & - & & \\
Sosyal Rutinlerle Bütünleşme & .10 & $.12^{*}$ & $.18^{* *}$ & $.49 * *$ & - & \\
Sosyal Medya Kullanımı & $.22^{* *}$ & $.25^{* *}$ & $.31^{* *}$ & $.92^{* *}$ & $.79 * *$ & - \\
$\bar{X}$ & 14.35 & 11.60 & 9.64 & 9.93 & 12.04 & 21.98 \\
$\mathrm{~S}$ & 7.04 & 6.52 & 5.14 & 4.96 & 3.18 & 7.08 \\
\hline
\end{tabular}

${ }^{* *} \mathrm{p}<.01,{ }^{*} \mathrm{p}<.05$

Aldatmaya yönelik niyet ile olumsuz aldatmaya yönelik tutum alt boyutu arasında düşük düzeyde ve negatif bir ilişki bulunmaktadır $(p<.05)$. Olumlu aldatmaya yönelik tutum ile aldatmaya yönelik niyet arasında pozitif bir ilişki olduğunu ancak olumsuz aldatmaya yönelik tutum alt boyutu ile arasında negatif bir ilişki bulunmaktadır $(p<.05)$. Sosyal bütünleşme ve duygusal bağlant (sosyal medya kullanımı alt boyutu) ile aldatmaya yönelik niyet, olumsuz aldatmaya yönelik tutum alt boyutu ve olumlu aldatmaya yönelik tutum arasında düşük ve pozitif bir ilişki vardır $(p<.05)$. Sosyal rutinlerle bütünleştirme ile sosyal bütünleşme ve duygusal bağlant (sosyal medya kullanımı alt boyutu), olumsuz aldatmaya yönelik tutum alt boyutu ve olumlu aldatmaya yönelik tutum arasında düşük ve pozitif bir ilişki vardır ( $p>.05$ ). Sosyal medya kullanımı ile aldatmaya yönelik niyet, olumsuz aldatmaya yönelik tutum alt boyutu ve olumlu aldatmaya yönelik tutum arasında düşük ve pozitif bir ilişki olduğunu ve Sosyal rutinlerle bütünleştirme ile sosyal bütünleşme ve duygusal bağlantı arasında yüksek ve pozitif bir ilişki vardır $(p<.05)$. Ancak, Sosyal rutinlerle bütünleştirme ile aldatmaya yönelik niyet arasında anlamlı bir ilişki bulunmamaktadır ( $p>05$ ). Aldatmaya yönelik niyetin, aldatmaya yönelik tutum ve sosyal medya kullanımı alt boyutları tarafindan yordanıp yordanmadığına ise çoklu regresyon analizi ile bakılmış ve bulgular Tablo 3'te verilmiştir.

Tablo 3. Genç yetişkinlerin Cinsiyet, Sosyal Medya Kullanımı Alt Boyutları ile Aldatmaya Yönelik Olumlu Olumsuz Tutuma İlişkin Çoklu Regresyon Analizi Sonuçları

\begin{tabular}{|c|c|c|c|c|c|c|c|c|}
\hline Bağımlı değişken & $\begin{array}{l}\text { Açıklayıcı Değişken- } \\
\text { ler }\end{array}$ & B & $\begin{array}{c}\text { Standart } \\
\text { Hata }\end{array}$ & Beta & $\mathrm{T}$ & $\mathrm{R}^{2}$ & $P$ & $\mathrm{~F}$ \\
\hline \multirow{11}{*}{ 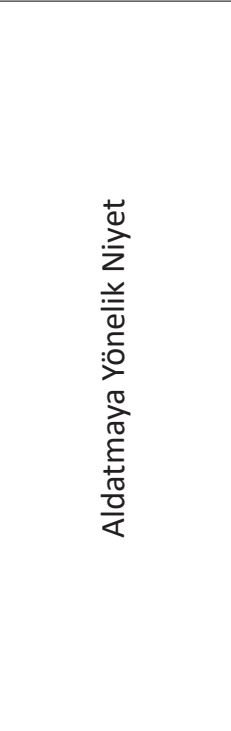 } & Sabit & 5.05 & 1.165 & & 4.34 & & $.000^{* *}$ & \\
\hline & Cinsiyet & .939 & .19 & .31 & 4.88 & & $.010 *$ & \\
\hline & $\begin{array}{l}\text { Sosyal Medya Kulla- } \\
\text { nımı }\end{array}$ & .055 & .05 & .16 & 2.30 & & $.031^{*}$ & \\
\hline & Sosyal Bütünleşme & .21 & .09 & .22 & 1.20 & & .055 & \\
\hline & ve Duygusal & & & & & .26 & & 35.12 \\
\hline & Bağlant & & & & & & & \\
\hline & $\begin{array}{c}\text { Sosyal Rutinlerle Bü- } \\
\text { tünleşme }\end{array}$ & .34 & .15 & .32 & 1.42 & & .053 & \\
\hline & Aldatmaya Yönelik & .195 & .51 & .18 & 3.81 & & $.00 * *$ & \\
\hline & Olumlu Tutum & & & & & & & \\
\hline & Aldatmaya Yönelik & -.532 & .07 & .39 & -8.05 & & $.00 * *$ & \\
\hline & Olumsuz Tutum & & & & & & & \\
\hline
\end{tabular}

${ }^{*} \mathrm{p}<.05,{ }^{*} \mathrm{p}<.01$, aDummy Değişkeni Erkek:0, Kadın:1 olarak kodlanmıştır.

Çoklu regresyon analizinin koşullarına bakıldığında otokorelasyon için Durbin Watson istatistiğine bakılarak değerlerin, 1.5-2.5 arasında olması, normal dağılım şartını sağlaması, değişkenler arasında doğrusal bir ilişki olması, bağımsız değişkenler arası korelasyon 0.80'den daha yüksek olmaması (Büyüköztürk, 2017) koşulları sağlandıktan sonra analiz gerçekleştirilmiştir. Çoklu regresyon analizinde her değişkenin $\mathrm{F}$ istatistiğine ayrı ayrı bakılarak anlamlılık testi yapılmıştır. Anlamlılık testinde modeline bakıldığında sosyal medya kullanımın boyutları olan sosyal bütünleşme ve duygusal 
bağlant ile sosyal rutinlerle bütünleştirme alt boyutları haricinde her düzeyde anlamlı olduğu görülmektedir $(p<.05)$.

Araştırmada kategorik bir değişken olan cinsiyet için kukla değişken düzenlenerek analiz yapılmıştır. Sosyal medya kullanımı, aldatmaya yönelik olumlu ve olumsuz tutum alt boyutları toplam puanlarının aldatmaya yönelik niyet toplam puanını yordayıp yordamadığına yönelik çoklu regresyon analizine ilişkin bulgular Tablo-3'te sunulmaktadır. Analize giren değişkenlerin genç yetişkinlerin aldatmaya yönelik niyetine derece açıkladıkları elde etmek için kullanılan regresyon analizine göre, açıklayıcı değişkenlerin yani; cinsiyet, sosyal medya kullanımı, aldatmaya yönelik olumlu-olumsuz tutum değişkenleri aldatmaya yönelik niyet değişkenini anlamlı şekilde yordadığı görülmektedir. Ancak, sosyal bütünleşme ve duygusal bağlantı ve sosyal rollerle bütünleşme alt boyutları anlamlılığa sahip olmadığı görülmektedir ( $p>05$ ).

Tabloya bakıldığında sırasıyla olumsuz aldatmaya yönelik tutum alt boyutu $\beta=.39, t=8.05, p=.000$ ), cinsiyet $\beta=.31$, $\mathrm{t}=4.88, p=.010$ ), olumlu aldatmaya yönelik tutum alt boyutu $\beta=.18, t=3.81, p=.000$ ) göreli olarak en önemli bağımsız değişken ve sosyal medya kullanımı $\beta=.351, t=5.56, p=.000$ ) en az göreli öneme sahip bağımsız değişken olduğu görülmektedir. Ayrıca çoklu regresyon analizinde cinsiyet değişkeni incelendiğinde, olumsuz aldatmaya yönelik tutum alt boyutu, olumlu aldatmaya yönelik tutum alt boyutu ve sosyal medya kullanımı değişkeninin, aldatmaya yönelik niyet puanı üzerinde erkeklerin puan ortalamaları kadınların puan ortalamalarından daha fazla olduğu belirlenmiştir.

Eğim katsayılarının işaretleri incelendiğinde, aldatmaya yönelik niyet değişkeni ile aldatmaya yönelik olumsuz tutum alt boyutu negatif yönlü ilişki olduğu ancak, cinsiyet, aldatmaya yönelikolumlu tutum alt boyutu ve sosyal medya kullanımı arasında doğru ve pozitif yönlü ilişkinin olduğu elde edilmiştir. Aldatmaya yönelik niyeti değişkeninin \%26'sını olumsuz aldatmaya yönelik tutum alt boyutu $\beta=.39, t=8.05, p=.000$ ), cinsiyet $\beta=.31, t=4.88, p=.010$ ), olumlu aldatmaya yönelik tutum alt boyutu $\beta=.18, t=3.81, p=.000$ ) göreli olarak en önemli bağımsız değişken ve sosyal medya kullanımı $\beta=.351, t=5.56, p=.000)$ tarafindan açıklamaktadır $\left(R^{2}=.26, p<.001\right)$.

\section{Tartışma / Sonuç}

Bu çalışmada genç yetişkinlerin aldatmaya yönelik niyetleri, aldatmaya yönelik tutum, sosyal medya kullanımı ve bazı değişkenler (cinsiyet, şu an ve devam eden ilişki durumu ve cinsel deneyim) açısından incelenmiştir.llk bulgudaki çapraz tablo incelendiğinde; ilişkilerine devam eden erkeklerin ve kadınların cinsel deneyime sahip oldukları, ancak ilişkisi olmayan kadınların ise cinsel deneyime sahip olmadıkları sonucuna ulaşılmıştr.Literatür incelendiğinde, Türkiye'de üniversite gençliği üzerinde yapılan çeşitli çalışmalarda genç yetişkinlerin çoğunun evlilik öncesi cinsel deneyime sahip olduğu ve bu çoğunluğun erkeklerin kızlara oranla önemli derecede evlilik öncesi cinsel ilişki yaşaması da (Aras, Orçın, Özan ve Şemin, 2004; Aydoğan, 2004; Özkan, 1994) bulguyu destekler niteliktedir. Benzer şekilde, Wellings ve arkadaşları (2006), 59 ülkede yapılan araştırmada evlilik öncesi cinsel deneyimin fazla olduğu ülkelerde erkeklerin kadınlara göre daha fazla evlilik öncesi ilişki yaşadıklarını tespit etmişlerdir. Japonya da üniversite öğrencileri ile yapılan araştırmada da erkek öğrencilerin \%90'ı, kız öğrencilerin ise \%83'üevlilik öncesi cinsel deneyim yaşamak istediklerini ifade etmektedir (Yamamoto, 2006).Fakat, Türkiye'de yaşayan genç yetişkinlerle yapılan bir araştırmada gençlerin \%54'ü evlilik öncesi cinsel deneyimin normal bir durum olmadığını belirtmektedir (Pınar, Doğan ve Öktem, 2009). Benzer şekilde Evcili, Cesur, Altun, Güçtaş ve Sümer (2013), kadınların \%81,2'si, erkeklerin \%66,9'u ilk cinsel deneyimlerini evlilik öncesi yaşamalarını uygun bulmadıkları sonucuna ulaşmışlardır.Araştırmanın bulguları değerlendirildiğinde; erkeklerin evlilik öncesi cinsel deneyimi uygun bulması ile birlikte geleneksel kültürden dolayı erkeklerin kızlara göre cinselliklerini özgürce yaşamalarının önünde herhangi bir engel bulunmadığını düşünmeleri gibi erkeklerin cinsel deneyiminin fazla olmasının ve evlilik öncesi cinsel birlikteliği daha fazla onaylamalarının etkili olduğu söylenebilir (Deniz, Tüfekçi ve Önder, 2015). Ayrıca cinsel deneyimle daha fazla ilgilenen bireylerin aldatma davranışının fazla olduğu bilinmektedir (Treas ve Giesen, 2000).Bütün bu sonuçlarla birlikte göz önüne alındığında, ilişkisi durumu ve cinsellik deneyiminin erkek ve kadınların aldatmaya yönelik tutum ve niyetlerini etkileyebileceği sonucu çıkarılabilir.

íkinci bulguya bakıldığında,genç yetişkinlerin, cinsiyet, sosyal medya kullanımı, aldatmaya yönelik tutumlarının,aldatmaya yönelik niyetlerini ne derece açıkladıkları çoklu regresyon analizi ile incelenmiş ve açıklayıcı değişkenlerin yani; cinsiyet, sosyal medya kullanımı, aldatmaya yönelik olumlu ve olumsuz tutum (aldatmaya yönelik tutum ölçeği alt boyutları) değişkenleri aldatmaya yönelik niyet değişkenini anlamlı şekilde yordadığı görülmektedir. Tutum, niyet ve davranış kimi zaman karıştrılmakta kimi zaman ise birbirinin yerine kullanılmaktadır. Tutum ve niyetin birbiri ile ilişkisi ve davranış üzerindeki yordayıcılığı düşünüldüğünde, aldatmaya yönelik niyet ve tutum ilişkisinin bilinmesinin aldatma davranışı ile ilgili önemli bilgiler sunacağı düşünülmektedir.Yine cinsiyet olgusunun da aldatma boyutunda ele alınıp değerlendirilmesinin açıklayıcı olacağı düşünülmektedir. Demirtaş (2004), genç yetişkinler ile yaptığı çalışmada kadınların erkeklere göre aldatmaya yönelik tutumlarının daha olumsuz olduğunu ifade etmektedir. Erkeklerin aldatmaya yönelik olumlu ve onaylayııı tutumda olmalarının aldatmaya yönelik niyetlerini olumlu şekilde etkilemesi de (Allen ve Baucom, 
2004; Atkins, Baucom, ve Jacobson, 2001; Buss ve ark., 1999) sonucu destekler niteliktedir.Çünkü aldatmaya yönelik olumsuz tutuma sahip bireylerin tutumlarının aldatmaya yönelik niyet ve davranışa dönüşmeyeceği ancak aldatmaya yönelik olumlu tutuma sahip bireylerin tutumlarının aldatmaya yönelik niyet ve davranışa dönebilme oranlarının yüksek olduğu bilinmektedir. (Azjen ve Fishbein, 2005; Demirtaş ve Tezer, 2013; Jones ve ark., 2011). Genç yetişkinler ve yetişkinlerle yapılan çalışmalarda; twitter ve facebook gibi sosyal medya kullanımının romantik ilişkilere zarar verdiği, bireyler arasında aldatmaya eğilimli olanların daha çok sosyal medya kullanmayı tercih ettikleri bilinmektedir (Clayton, Nagurney ve Smith, 2013; Russell ve Clayton, 2014). Benzer şekilde, Saleh ve Mukhtar, (2015) yaptıkları çalışmada, sosyal medya kullanımının evliliklerde boşanmaya ve ilişkilerde aldatmaya neden olduğunu ifade etmektedir. Stetzer, (2014) sosyal aldatma ile ilgili yapılan çalışmada facebook kullanan erkeklerim kadınlara göre daha fazla aldatma davranışında bulundukları görülmüştür.Ayrıca, sosyal medya uygulamalarının yoğun şekilde kullanılmasının ergenlerin daha fazla aldatma davranışında bulundukları bilinmektedir (Schneider, Weiss ve Samenow, 2012; Tsikerdekis, Zeadally, 2014). Evli ve birlikte yaşayan bireylerle yapılan araştırmada sosyal medya sitelerini kullananların aldatma davranışı gösterdiklerini bulmuşlardır. Evli ve birlikte yaşayan bireylerin aldatma davranışı, romantik ilişkilerindeki memnuniyeti olumsuz etkilediğini bulmuşlardır (Brandon, Michelle ve Cravens, 2017).

Geçmişte yüz yüze kurulan ve yürütülen ilişkilerin yerini, artı sosyal teknolojinin ürettiği yeni bir ilişki tarzı almaktadır. Sosyal medya kullanımı kişiler arası etkileşimi ve iletişimi, zaman ve çevre sürekliliğinde bireyde değişim ve gelişim meydana getirmektedir. Bu değişim ve gelişim, kişilerarası ilişkilerde olumlu ve olumsuz durumlar yaratabilmektedir. Bu araştırmada sosyal medya kullanımının romantik ilişkileri etkilediği görülmektedir. Her geçen gün sosyal paylaşım ağları ile romantik ilişki kuran kişi sayısı artmaktadır. Bu ağlar arasında sosyal medya, ortak ilgi alanları olan insanları bir araya getiren bir medya ortamı olarak dikkat çekmektedir. Sosyal medya ortamında sevgi açlığını ve duygusal boşluğunu doyurma gayreti içerisine giren bireyler, sosyal medyayı aşırı ve amacı dışında kullanmaya yönelebilmekte ve aldatma davranışında bulunabilmektedir. Genç yetişkinlerin sosyal medyanın aşırı ve amaç dışı kullanımı arttıkça aldatmaya yönelik tutumları olumlu yönde artacaktı. Bireylerin aldatmaya yönelik tutumu arttkça aldatmaya yönelik niyetini de artırmış olacaktır. Dolayısıyla sosyal medya kullanımını aşırı yoğun ve amacı dışında kullananların aldatma davranışlarını olumlu etkileyeceği söylenebilir.

Sonuç olarak; genç yetişkinlerin aldatma niyetlerinin, cinsiyet, sosyal medya kullanımı ve aldatmaya yönelik tutum değişkenleri tarafindan açıklanmaktadır.Genç yetişkinlerin, aldatma davranışlarının azaltılması için psikososyal müdahale gruplarının oluşturulması, uzmanlar tarafindan aldatma davranışının ve sosyal medya kullanımı ile ilgili zararları ve olası sonuçları ile ilgili konferans, seminer verilmesinin ve eğitim ile ilgili içerikler planlanması faydalı olacağı önerisi yapılabilir. Sosyal medya kullanımı ve romantik ilişkilerle ile ilgili verilecek eğitimler bireylerin farkındalık kazanmasını sağlayarak aldatmaya yönelik tutum ve niyetlerinin oluşması engellenebilir.Ayrıca cinsiyet dağıımı daha yakın ve katılımcı sayısı daha geniş olan bir örneklemle çalışılması önerilmektedir. Yapılacak yeni çalışmalarda aldatmaya yönelik niyet davranışının affedicilik, psikolojik sağlamlık, öz-anlayış, romantik kıskançlık gibi farklı kavramlarla da ilişkisine bakılması önerilmektedir.

Araştırmada, Türkiye'de aldatmaya yönelik niyet, tutum ve sosyal medya kullanımını inceleyen ilk çalışmadır. Bu bakımdan alana katkısı olmasına rağmen birtakım sınırılıkları bulunmaktadır. Örneklem sınırlı sayıda genç yetişkinden oluşmaktadır. Yapılacak çalışmaların daha farklı örneklemlerle desteklenmeye intiyaç duymaktadır. Araştırmada çoklu regresyon analizi kullanılmıştı. Aldatmaya yönelik niyet üzerinde etkili olabilecek gizil değişkenler ve aracı değişkenlerin tespiti için ileri düzey istatistikler tercih edilebilir. Ayrıca genç yetişkinlerin aldatma nedenlerini ve etkili olabilecek faktörleri anlamak adına derinlemesine bilgi toplamak için nitel verilerle desteklemenin faydalı olacağı düşünülmektedir.

\section{Kaynakça}

Ajzen, I. \& Fishbein, M. (2005). The influence of attitudes on behavior. In D. Albarracin, B. T. Johnson, \& M. P. Zanna (Eds.), Handbook of attitudes andattitude change. (pp.173-221). Hillsdale, NJ: Erlbaum.

Allen, E. S. \& Baucom, D. H. (2004). Adult attachment and patterns of extradyadic involvement. Family Process, 43, 467-488.

Aras Ş, Orçın E, Özan S. \& Şemin S. (2004). Dokuz Eylül Üniversitesi Öğrencilerinin Cinsel Bilgi, Tutum ve Davranışları. Sağlık ve Toplum Dergisi. 4(1): 23-28.

Atkins, D. C., Baucom, D. H. \& Jacobson, N. S. (2001). Understanding infidelity: Correlates in a national random sample. Journal of Family Psychology, 15, 735-749.

Aydoğan A. (2001). MarmaraÜniversitesi Araştırdı: Türk Gençliği Cinselliği Bilmiyor;http_//_www.milliyet.com/2001/055/19/_yasam/_ yas03b.html adresinden elde edildi.

Blow, J. A. \& Hartnett, K. (2005). Infidelity in committed relationships I: A methodological review. Journal of Marital and Family Therapy, 31(2), 183-216 
Bostancı,M., (2010).Sosyal medyanın gelişimi ve iletişim fakültesi öğrencilerinin sosyal medya kullanım alışkanlıkları.(Yayınlanmamış Yüksek Lisans Tezi), Erciyes Üniversitesi Sosyal Bilimler Enstitüsü, Kayseri

Brandon, M., Michelle, D. \& Cravens, J., D. (2017). Do you have anything to hide? Infidelity-related behaviors on social media sites and marital satisfaction.Computers in Human Behavior, 10(66):88-95.

Bulunmaz, B., (2011). Otomotiv Sektöründe Sosyal Medyanın Kullanımı ve Fiat Örneği.Global Media Journal, Yeditepe Üniversitesi, 2(3), ss:19-50.

Buss, D., Shackelford, T., Kirkpatrick, L., Choe, J., Lim, H., Hasegawa, M. \& Bennett, K. (1999). Jealousy and the nature of beliefs about infidelity: Tests of competing hypotheses about sex differences in the United States, Korea, and Japan. Personal Relationships, 6(1), 125-150.

Büyüköztürk, Ş. (2017). Sosyal bilimler için veri analizi el kitabı. Ankara: Pegem.

Clayton R, Nagurney A, Smith J. (2013). Cheating, breakup, and divorce: is Facebook use to blame?.Cyberpsychology, Behavior, \& Social Networking; 16, 717-720.

Demirtaş, H.A. (2004) Yakın ilişkilerde kıskançlık bireysel, ilişkisel ve durumsal değişkenler değişenler.(Doktora Tezi), Ankara Üniversitesi SosyalBilimler Enstitüsü, Ankara.

Deniz, Ü., Tüfekci, A , Önder, Ö . (2015). Öğretmen Adaylarının Cinsellik Konusundaki Tutumlarının Cinsiyet ve Cinsel Deneyimlerine Göre İncelenmesi. Karadeniz Sosyal Bilimler Dergisi, 5 (9).

Dikme, G. (2013).Üniversite öğrencilerinin iletişimde ve günlük hayatta sosyal medya kullanım alışkanlıkları: Kadir Has Üniversitesi örneği, (Yayımlanmış Yüksek Lisans Tezi), Kadir Has Üniversitesi Sosyal bilimler Enstitüsü, İstanbul.

Ergenç, A. (2011). Web 2.0 ve sanal sosyalleşme: facebook örneği, (Yayınlanmamış Yüksek Lisans Tezi), Maltepe Üniversitesi, İstanbul.

Evcili, F., Cesur, B., ALTUN, A., Güçtaş, Z. ve Sümer,H. (2013). Evlilik öncesi cinsel deneyim: ebelik bölümü öğrencilerinin görüş ve tutumları, Gümüşhane Üniversitesi Sağlık Bilimleri Dergisi, 2(4).

Hair, J. F., C. Black, W. C., Babin, B. J. \& Anderson, R. E. (2010). Multivariate Data Analysis, Englewood Cliffs, Prentice Hall: NJ.

Hansen, G. L. (1987). Extradyadic relations during courtship. Journal of Sex Research, 23, 382-390.

Jones, D.N., Olderbak, S.G. \&Figueredo, A.J. (2011). The intentions towards infidelity scale. 3. edition. (Ed. T.D. Fisher, C.M. Davis, W.L. Yarber, \& S.L. Davis Handbook of Sexuality-Related Measures.(pp. 251- 253) New York: Routledge

Lehr, U. (1994). Yaşlanmanın psikolojisi. İstanbul: Bilimsel ve Teknik Yayınları Çeviri Vakfi.

Moss, B. F., Schwebel, A. I. (1993). Marriage and romantic relationships: defining intimacy in romantic relationships. Family Relations, 42, 7-31.

Özan S, Aras Ş. \&Şemin S. (2004). Dokuz Eylül Üniversitesi Tıp Fakültesi Öğrencilerinin Cinsel Tutum ve Davranış Özellikleri. Dokuz Eylül Üniversitesi Tıp Fakültesi Dergisi, 18(1),27-39.

Özkan H. (1994). Üniversite gençliğinin aile planlaması ve cinsel yolla bulaşan hastalıklardan korunmaya ilişkin yaklaşımları. (Yayınlanmamış Yüksek Lisans Tezi). İstanbul Üniversitesi, İstanbul.

Parker T. \&Wampler K. (2003). How bad is it? Perceptions of the relationship impact of different types of internet sexual activities. Contemp Fam Ther, 25:415-429.

Pınar G, Doğan N. \&Ökdem Ş. (2009). Özel Bir Üniversitede Okuyan Öğrencilerin Cinsel Sağlıkla İlgili Bilgi Tutum ve Davranışları. Tıp Araştirmaları Dergisi. 7(2): 105-113.

Ross, C. M. (2006). A Qualitative Study Exploring Characteristics of Churches Committed to Intergenerational Ministry. ProQuest. Saint Louis University, A Bell Howellnformation Company, University Microfilms International, USA, s. 26

Russell B. \& Clayton, MA, (2014). The Third Wheel: The Impact of Twitter Use on Relationship Infidelity and Divorce, Cyberpsychology, Behavior, And Social Networkıng,17(7).

Saleh, M. \&Mukhtar, J. I. (2015). Social Media and Divorce Case Study of Dutse L.G.A. Jigawa State, IOSR Journal Of Humanities And Social Science20(5), 54-59.

Schneider, J. P., Weiss, R., \& Samenow, C. (2012).Is it really cheating? understanding the emotional reactions and clinical treatment of spouses and partners affected by cybersex infidelity. Sexual Addiction \& Compulsivity, 19:123-139.

Stetzer, M. (2014). Social cheating: A look at social media's influence on infidelity: http://www.totaldivorce.com/process/socialmedia(Accessed on 1st Sept. 2017).

Treas, J. \&Giesen, D. (2000). Sexual infidelity among married and cohabiting americans. Journal of Marriage and Family,1(62):48-60

Tsikerdekis, M. \& Zeadally S. (2014). Online Ddception in social media. Communications of the ACM, 9/57):72-80

Vural, Z. \&Bat, M. (2010). Yeni Bir İletişim Ortamı Olarak Sosyal Medya: Ege Üniversitesi İletişim Fakültesine Yönelik Bir Araştırma. Journal of Yasar University, 5(20).

Wellings K., Collumbien M, Slaymaker E, Singh S, Hodges Z, Patel D. \&Bajos N. (2006).Sexual behaviour in context: a global perspective.The Lancet,11(368):1706-28. 
Wiederman, M. W. \&Hurd, C. (1999).Extradyadic involvement during dating. Journal of Social and Personal Relationships, 16, 265-274 Yamamoto, K. (2006). Cross-Sectional Study On Attitudes Toward Sex And Sexual Behaviour Among Japanese College Students. Journal of Physiological Anthropology, 25, 221-227

Yeygel Çakır, S., (2011). Web Siteleri ve İkna. Konya: Tablet Yayınları. 